\title{
Infected with Scabies Again? Focus in Management in Long-Term Care Facilities
}

\author{
Chong Yau Ong $1,2, *$ and Farhad Fakhrudin Vasanwala ${ }^{1,2}$ \\ 1 Department of Family Medicine, Division of Medicine, Sengkang General Hospital, Singapore 544886, \\ Singapore; farhad.fakhrudin.vasanwala@singhealth.com.sg \\ 2 SingHealth Duke-NUS Family Medicine Academic Clinical Programme, Singapore 544886, Singapore \\ * Correspondence: ong.chong.yau@singhealth.com.sg; Tel.: +65-6930-2941
}

Received: 28 November 2018; Accepted: 22 December 2018; Published: 29 December 2018

\begin{abstract}
Scabies is a significant public health condition in long-term care facilities, plaguing even developed countries. Although treatments are available, eradication and control of scabies cases still remain a challenge due to delays in diagnosis and difficulties in maintaining preventive and surveillance measures. Prompt treatment of patients and their contacts that are affected, along with concomitant education of health staff and family members, are paramount. Environmental disinfestation is also a concern.
\end{abstract}

Keywords: scabies; mites; long-term care

\section{Introduction}

Scabies is often a neglected parasitic disease. It has long been known to human beings, first described by the renowned physician Jeremy Thriverius of the Habsburgian Low Countries during the 16th century. The causal relationship between skin infestation and the scabies mite was first established by Giovan Cosimo Bonomo, an Italian physician, and the apothecary Diacinto Cestoni [1]. Scabies is a significant public health condition both in resource-poor and developed countries [2], affecting individuals of every age and socioeconomic status [3]. Incidentally, the role of poor hygiene in scabies occurrence has been overestimated and is probably more attributable to overcrowding [4-6]; this is noted in institutional outbreaks, where high standards of cleanliness are observed $[7,8]$. Outbreaks in residential and long-term care facilities, however, are usually caused by diagnosis delay and are therefore difficult to control [9].

\subsection{Epidemiology}

A systematic review of population-based studies found the highest prevalence of scabies in Papua New Guinea, Panama, and Fiji $[10,11]$. Scabies caused $0.21 \%$ of Disability-Adjusted Life Years (DALYs) from all conditions studied by the Global Burden of Disease (GBD) 2015 [11]. A review of institutional scabies outbreaks globally revealed that $48 \%$ of the outbreaks occurred in residential care facilities for the elderly [12,13]. Prevalence of institutional scabies is probably underestimated [14].

In one review of 206 outbreaks in elderly care facilities caused by 37 pathogens, scabies was the fifth most reported pathogen after influenza and noroviruses, Salmonella spp., and Group A Streptococcus [15]. Scabies has high median attack rates for health care workers at $36 \%$, only slightly less than Chlamydia pneumonia (41\%) and noroviruses (42\%) [15]. 


\subsection{Transmission}

This ectoparasite infestation is caused by the mite Sarcoptes scabiei variety hominis. S. scabiei is a member of the family Sarcoptidae, within the class Arachnida. Both male and female mites are invisible to the unaided eye; the maximum adult size is $0.45 \mathrm{~mm}[4,16]$.

Scabies is transmitted through skin-to-skin contact, though less frequently through fomites (inanimate objects capable of transmitting an infectious organism such as clothing, towels, and bed linens) [17-20]. Among adults, sexual contact is an established mode of transmission [3].

Mites dislodged from an infested individual use odor and heat to locate a new host [4]. The probability of being infected is related to the number of mites on the infested individual and the length of contact $[3,17]$.

Away from the host, mites are able to survive and stay capable of infestation for $24-36 \mathrm{~h}$ at $21^{\circ} \mathrm{C}$ with $40-80 \%$ relative humidity [21]. In colder temperatures and higher humidity, they can survive even longer. The mites have been reported to be capable of survival for 19 days at $10{ }^{\circ} \mathrm{C}$ and $97 \%$ relative humidity, although they are unable to move and penetrate skin at temperatures below $20^{\circ} \mathrm{C}[4,21]$. Scabies mites survive less than $24 \mathrm{~h}$ in a temperature of $34^{\circ} \mathrm{C}$ [2]. To a lesser extent, transmission can happen through fomites $[18,19,21-23]$.

\subsection{Parasite Lifecycle and Incubation Period}

Female mites burrow into the epidermis, while male mites explore the skin for an unfertilized female. Female mites live for $4-6$ weeks, producing $2-4$ ova a day [16,24]. A single female mite can produce up to 40 ova during her lifetime, the larvae hatching 2-4 days thereafter. Larvae molt into protonymphs (3-4 days) and then tritonymphs (2-5 days) before turning into adult male or female mites (5-6 days). In total, mature adults develop within 10 to 14 days [2].

The incubation period for naïve patients without previous exposure to scabies is $2-6$ weeks. However, this period is shorter in people who have been previously infested, whereby symptoms typically develop within 1 to 5 days of re-exposure due to rapid sensitization [3,18].

\section{Clinical Presentation}

The two major clinical variants of scabies are classic and crusted. Classic scabies, the most common presentation, is associated with a relatively low mite burden (approximately 10-15 mites on the body). Crusted scabies usually occurs in older adults, individuals with dementia, immunocompromised individuals, and individuals with severe neurological disease $[9,25,26]$. It is associated with a higher mite burden of up to millions of mites on the body [27]. Other forms of scabies include bullous scabies that can mimic bullous pemphigoid, scabies incognito, and hidden scabies [28].

\subsection{Distribution of Rash}

The pathognomonic signs of scabies are burrows, erythematous papules, along with the symptom of pruritus (nocturnal predominance) [2,4]. Burrows are serpiginous, whitish lines in the upper epidermis, measuring several millimeters in length. Typical areas where signs of infestation can be observed are the interdigital spaces of the hand, flexural aspect of the wrists, elbows, penis shaft, nipples, buttocks, axillae, and periumbilical area.

In infants and the elderly, classic scabies can present atypically on the head, face, back, and diaper area $[2,24,29]$. Crusted (or Norwegian) scabies affect patients with HIV-infection, human T-cell lymphotropic virus type 1 , other immunocompromised patients, and those with sensory and motor neuropathy or dementia [29-32]. Sometimes it affects persons without apparent risk factors [3]. Lesions are described as erythematous, hyperkeratotic, psoriasiform, warty, and exfoliating, scaly rash over the scalp, face, fingers, genitalia, and even nails [4,29]. Inappropriate long-term application of potent topical steroids, especially in the elderly, can lead to crusted scabies [29]. 


\subsection{Host Immune Response}

Delayed type IV hypersensitivity, established as a mechanism leading to signs and symptoms of scabies, occurs as a reaction against the scabies mite's saliva, eggs, or feces (sycbala) [18]. The reaction can be delayed for up to four weeks, which accounts for long latency of the disease [33].

Both cell-mediated host immune response and humoral response play roles in the host immune response [2,18]. Increased serum levels of IgG and IgE (combined with peripheral eosinophilia) are not protective against reinfestation [2].

\subsection{Complications}

Scabies mites are not known to transmit secondary infections. However, severe scratching can lead to secondary skin infection. Secondary skin infections are not limited to boils, cellulitis, pyoderma, or lymphangitis due to Streptococcal pyogenes. Streptococci and staphylococci have been isolated from skin burrows as well as mite fecal pellets, suggesting that the mites themselves may contribute to the spread of pathogenic bacteria [5]. Bacterial superinfections, however, are uncommon in immunocompetent adults living in Western countries [34]. Secondary infection of scabies with S. pyogenes is a major precipitant of acute post streptococcal glomerulonephritis and possibly rheumatic fever $[4,35]$.

\section{Diagnosis}

Diagnosis is based on the contact history of the patients, health care workers, or even family members. The combination of pruritic eruptions, characteristic lesions and their distribution, and the identification of mites, eggs, or feces on skin scrapings confirm the diagnosis.

In practice, burrows are often obliterated by bathing, scratching, formation of crusts, or superinfection [4]. Visibility of burrows can be improved with an ink burrow test, where burrows will absorb the ink and be readily apparent as ink-filled wavy lines where the mite has tunneled, called the stratum corneum [36].

The usual method of obtaining skin samples is accomplished through skin scraping. In this method, the scalpel should ideally be oil-covered as the oil helps to keep the scraped content adhering to the blade [2]. Multiple superficial skin samples should be obtained from characteristic lesions by scraping laterally across the skin cautiously to avoid bleeding [24]. Scrapings are then placed on a covered slide for direct microscopic examination.

Video dermatoscopy is suitable for clinching diagnosis in children. With a magnification of up to 600 times, mites and burrows can be identified [37]. Use of a handheld dermatoscope requires training to recognize the typical "jet with condensation trail" pattern. Performed by a trained practitioner, dermatoscopy yields high accuracy in diagnosing scabies [38,39].

Epiluminescence microscopy using dermatoscopy has also been used in dermatology clinics to identify in vivo mites with good sensitivity [40]. Incident light microscopy (with a magnification of up to $200 \times$ ) and reflectance-mode confocal microscopy have also been found to have high diagnostic sensitivity [41,42]. Serology tests have yet to be successful in human infestations [43]. Complementary DNA libraries have been constructed for $S$ scabiei var. hominis, but commercial molecular diagnostic tests have not yet been developed [38,44,45].

The International Alliance for the Control of Scabies (IACS) recently released a consensus on diagnosis of scabies with high agreement (Table 1) [46]. 
Table 1. The 2018 International Alliance for the Control of Scabies (IACS) criteria for the diagnosis of scabies.

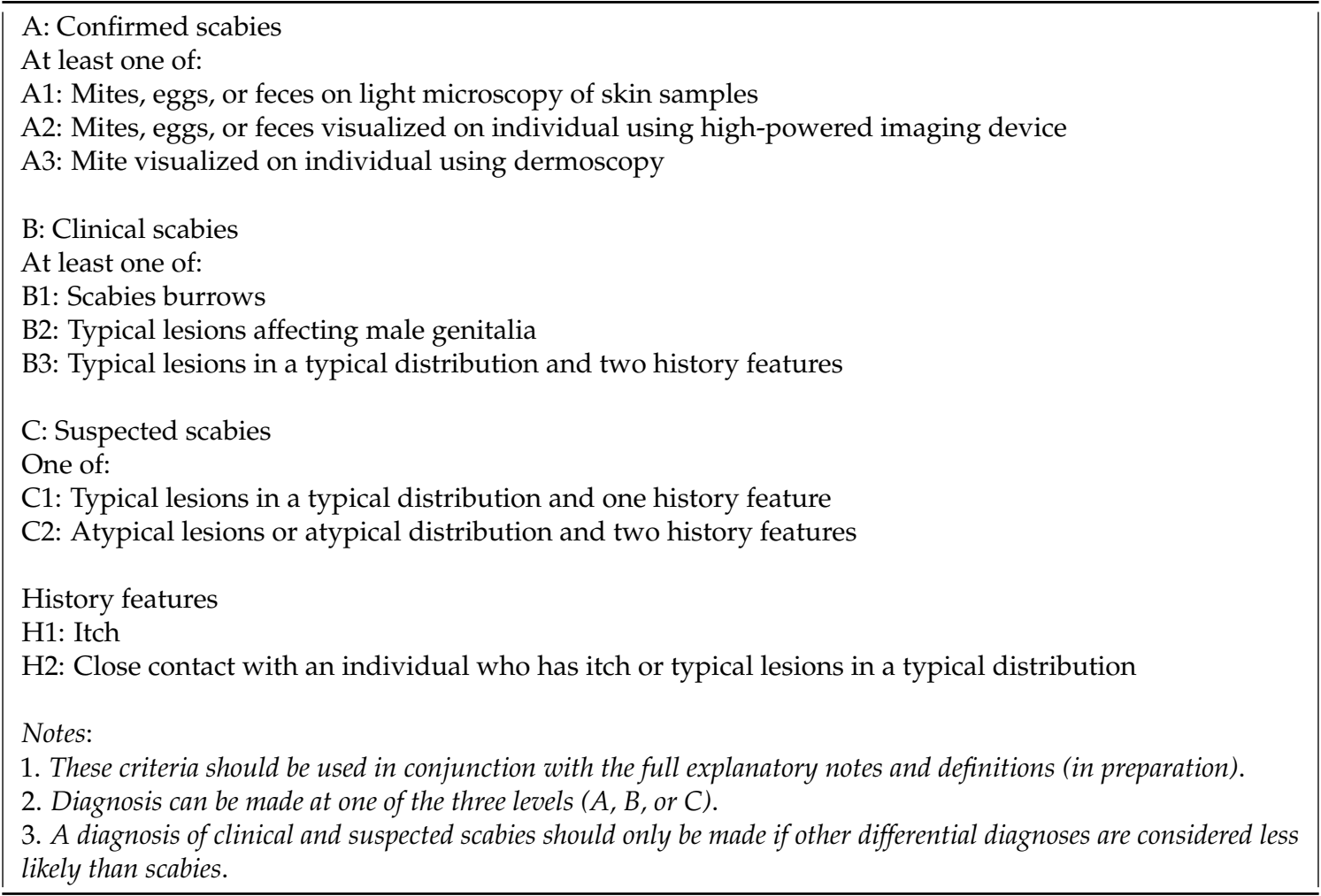

Identification and early treatment of suspected scabies is critical especially in residential or care facilities. Delays in diagnosis have been reported in nursing homes where it was misdiagnosed as eczema and other skin conditions by visiting general practitioners (GPs) until that diagnosis was superseded by another GP [25]. Most nursing homes and institutional residential or care facilities do not have access to specialist dermatological support [25].

\section{Differential Diagnoses}

The list of differential diagnoses is extensive and includes atopic dermatitis, contact dermatitis, folliculitis, impetigo, papular urticarial, bites (from midges, fleas, lice, bedbugs, and other mites), and tinea [2,3]. Nearly all pruritic dermatoses have to be considered differential diagnoses [4].

\section{Management}

\subsection{Principles of Treatment}

The principle of treatment of scabies is rapid isolation and treatment of the index case, identifying contacts, and environmental disinfestations [47]. It is imperative for the close contacts of individuals diagnosed with scabies to be treated simultaneously because they may have been infected without yet manifesting the symptoms, and so act as reservoirs for infection [48-51]. Isolation and locking of doors for residents with dementia and wandering behavior is essential, although it can be distressing to them and staff [25].

\subsection{Topical and Oral Agents}

Most scabies infestations are treatable with scabicides. It is essential that steps for environmental disinfection take place simultaneously with medical treatment. Topical treatments typically require application from the neck down to the soles of the feet (including fingernails and toenails) for 
duration of many hours. There is no international consensus on the appropriate schedule of treatment, and recommendations in one jurisdiction may not be applicable in others [14,48,52].

In a review of interventions for scabies, permethrin was found to be more effective than other scabicides [53]. A recent review found no difference detected in the efficacy of permethrin in comparison to ivermectin [54]. Although malathion has been used with success in many centers, there are no trials to compare the effectiveness of malathion against other scabicides [53]. Table 2 summarizes commonly used treatments for scabies.

Table 2. Summary of treatments for scabies.

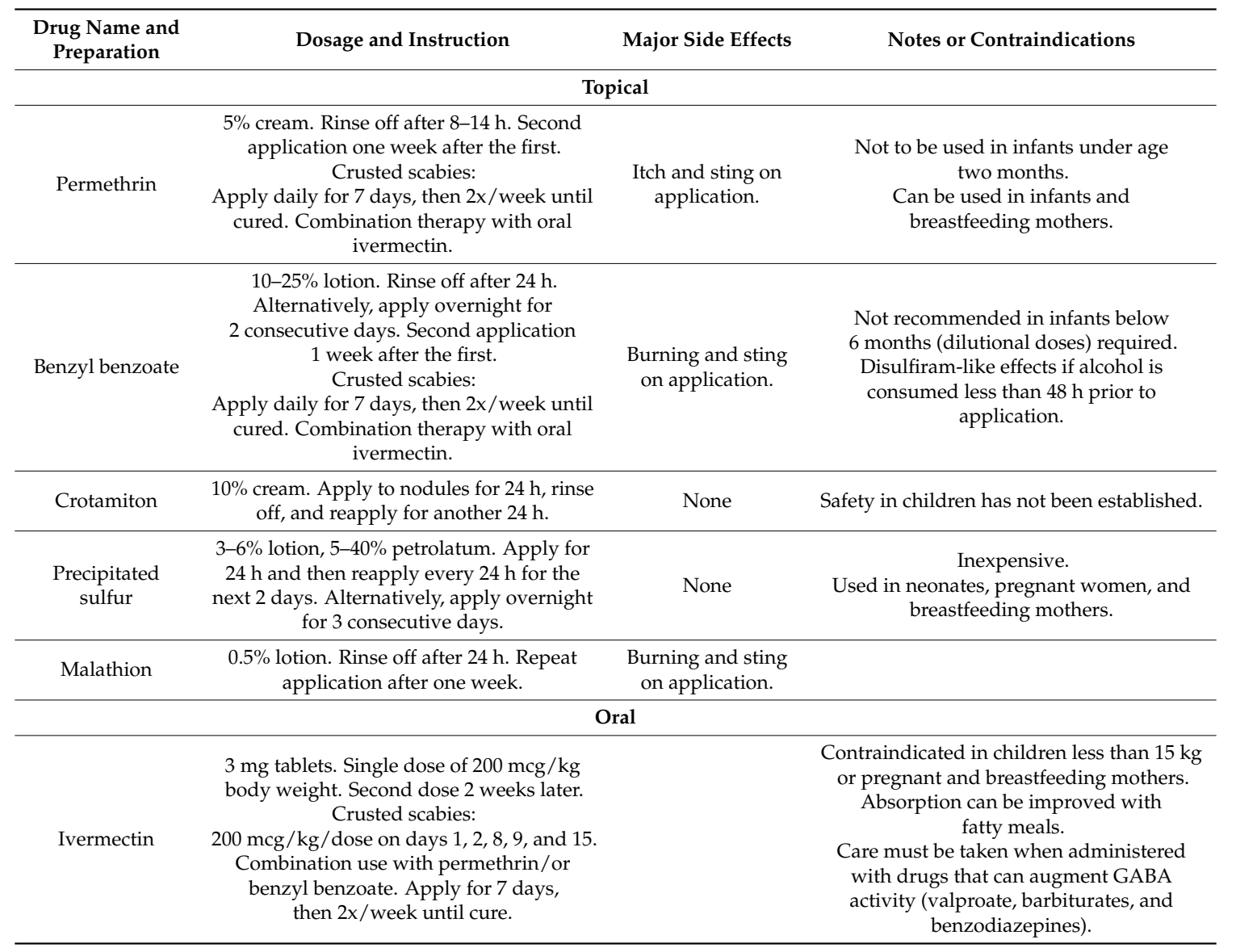

Efficacy of one application in comparison to two applications has not been formally tested [16]. Application of topical therapy above the neck level should be considered in children and the elderly who have significant scalp involvement.

Antihistamines and emollients are useful for symptomatic management of itch, including medication-related post-scabetic itch [49]. Topical keratolytics such as salicylic acid can be used to treat crusted scabies. It is applied on days where scabicide is not applied.

\subsection{Drug Resistance and Other Treatments}

Of late, the resistance to scabicides has been increasingly reported [55-59]. Four different players that could potentially contribute to scabicide resistance have been identified as follows: (a) voltage-gated sodium channels, (b) glutathione S-transferase (GST), (c) ATP-binding cassette transporters, and (d) ligand-gated chloride channels [57].

Moxidectin (an established treatment of scabies in dogs and sheep) is currently being evaluated as an oral agent for scabies. It is related to ivermectin and has the same mechanism of action, but is more lipophilic (retains in tissue longer). The prospect of moxidectin as future therapy for scabies has been promising [60-62]. 
Vaccination has been shown to have some potential in controlling scabies epidemics [63]. The development of a vaccine against scabies is still being conducted $[57,64]$.

\subsection{Environmental Disinfestation}

Isolation rooms should be cleansed thoroughly. Residential and care facility staff should avoid direct skin-to-skin contact by using protective garments such as gowns and gloves. Correct handling of disposed protective garments should also be observed.

Infested individuals' bedding, clothing, towels, and personal bed jackets should be separately machine-laundered using hot water above $75^{\circ} \mathrm{C}$, followed by hot dryer cycles. No special processing such as autoclaving or bleaching is required [16]. Items that are unable to be laundered, such as shoes, should be placed in a plastic bag and left for $72 \mathrm{~h}[16,19]$. Amenities and equipment such as geriatric chairs, commodes, and toilets should not be shared until $24 \mathrm{~h}$ post treatment [19]. Chloramine $5 \%$ has been used to disinfect rooms of infested individuals [47].

\subsection{Management of Complications or Treatment Failure}

Resolution of active lesions and alleviation of pruritus indicate that therapy has likely been successful. Having said that, pruritus may persist two to four weeks after successful treatment and can be part of the resolution process or caused by post-scabetic dermatitis. In this case, scabies scrapes can be repeated post wash-out of topical scabicides to confirm eradication.

Confirmed treatment failure can be largely attributed to ineffective application of topical scabicides and incomplete environmental control [65]. Alternative therapies should be considered in the case of resistance to initial therapies.

\subsection{Management of Outbreak and Prevention Program}

In residential homes and care facilities, early recognition of scabies is essential to prevent outbreaks [50]. Diagnosis may be delayed because of the less familiar way that scabies can present in the elderly [66]. Once an outbreak occurs, prompt control of the index patient and rapid tracing of contacts to identify secondary cases are necessary (Figure 1) [48,49]. When prolonged exposure to a case of scabies results in multiple secondary cases, institution of simultaneous mass prophylaxis is the most efficient strategy for terminating the outbreak and can be implemented without ward closure, although the logistic aspects are considerable [50]. However, an aggressive approach of the minimization of transmission pathways such as the reduction of staff rotation, cancellation of community activities, and if possible, of new admissions (ward closure), has also been recommended [67].

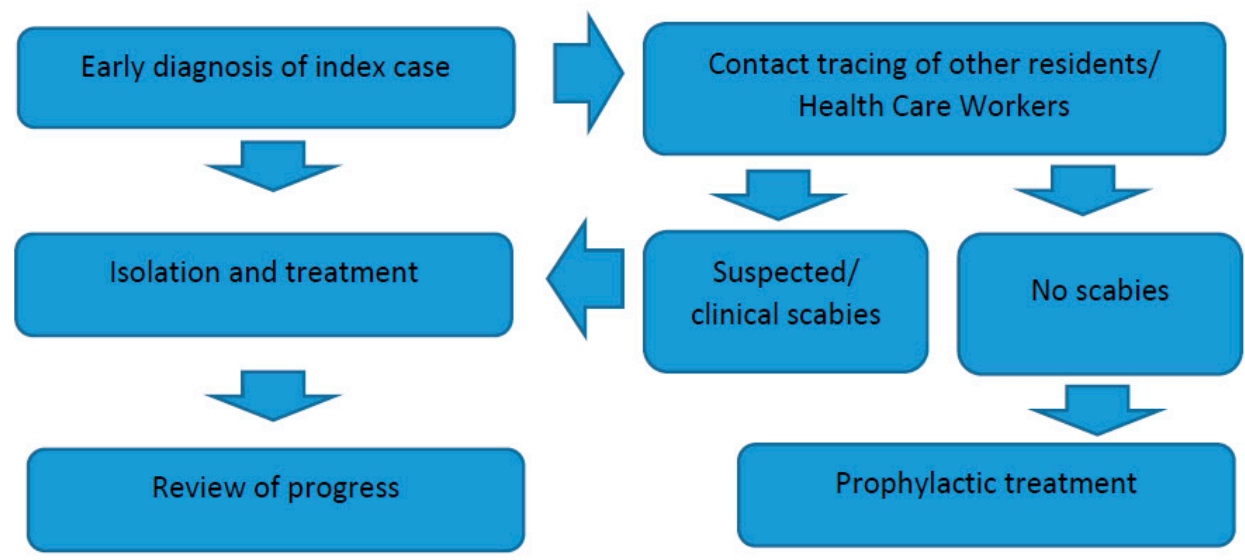

Figure 1. Workflow for management of scabies in long term care facilities.

Due to the unavailability of well-designed, randomized controlled trials (RCTs) to provide conclusive evidence of prophylactic measures, it is unclear whether prophylaxis is more appropriate 
than a "wait and see" approach, whereby contacts are educated regarding the possibility of infection and advised to seek medical consultation should they develop symptoms suggestive of infection $[48,49]$.

In the review of prevention strategies, the authors summarized the concerns and barriers for prophylaxis (Table 3) [48]. In general, control of large outbreaks is distressing and requires significant effort in terms of time, money, organization, coordination, and teamwork among healthcare staff $[25,68]$.

Table 3. Concerns and challenges in mass prophylaxis.

1) Commitment and willingness of exposed contacts to undergo treatment [69].

2) Substantiating the degree of contact of exposed individuals with the index case, including those who are unable to consent for treatment [70].

3) Side effects of therapy [14].

4) Possibility of drug resistance against anti-scabetic treatments $[49,56]$.

5) Stigma associated with diagnosis, which may lead to reluctance in disclosure of diagnosis to close contacts $[4,12,67]$.

6) Cost associated with providing medical treatment to all contacts $[12,25,71]$ and getting medications in bulk [25].

7) Logistical difficulties in identifying all contacts of an index case $[12,25,69]$.

Long-term care facilities should possess a scabies prevention program. Such a program should include assessment of skin, hair, and nails for all new admissions as they arrive [72]. Any lesions suspected to be scabies and other dermatological conditions should be escalated to the physician. Time should be allocated to conduct this assessment periodically. However, in practice, long-term care facilities often suffer inadequate staffing.

Prolonged surveillance in the eradication of scabies in long-term care facilities is needed due to the dynamics of residents and rotation of staff [73]. New cases can occur due to the transfer of new residents with unrecognized scabies, as well as existing residents who returned to the facilities after contracting scabies from another hospital.

\subsection{Contact Tracing}

Concurrent treatment of contacts and individuals diagnosed with scabies is important, as the onset of symptoms is often delayed and therefore contacts may have active scabies while they are asymptomatic of pruritus. Family members that co-habit, including domestic workers, as well as family members and visitors of the diagnosed individuals up to six weeks prior to the diagnosis should be identified and treated.

In residential and care facilities, all persons that are in contact with the affected individuals should be traced and treated. This includes doctors, nurses, social workers, volunteers, therapists, assistants, porters, security officers, and visitors. This can be done through the checking of electronic systems used for keeping track of staff and visitors who enter the affected ward or cubicle. Registration of staff or visitors using books should be done and subsequently traced during an outbreak if the entrances to the wards are not digitally captured. This can be logistically challenging in nursing homes and care facilities with day care services, including short and long term patients [47]. Identified contacts should be treated with the same regimen used for classic scabies. Cooperation and compliance of health care workers and visitors is needed for successful treatment [74].

Restriction of staff rotation in the care facility has been identified as one of the steps of the successful control of outbreaks [73]. Nurses who are caring for symptomatic patients and residents in the same ward are required to examine themselves regularly, and if found to be symptomatic, are instructed to contact the ward employee in charge in order to be excused from work [75]. Infested staff can return to work $24 \mathrm{~h}$ after their first scabicide treatment [19]. 
In resource-adequate settings, we suggest a multi-disciplinary team consisting of a minimum of six members to address the treatment and preventive aspects of scabies infestation (Figure 2). Meetings should be conducted to update the progress of the treatment of cases and their contacts and identification of new cases [67]. In resource-limited settings, public health nurses or trained individuals can be tasked to chair, coordinating the preventive measures.

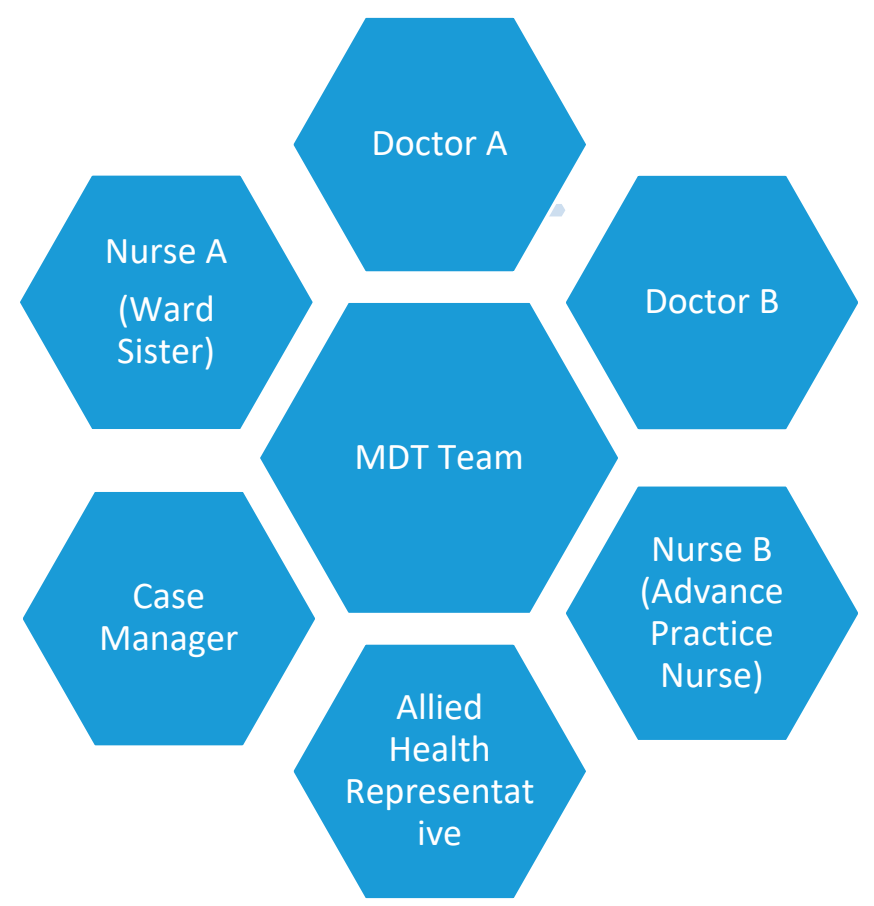

Figure 2. Multi-disciplinary (MDT) Team. Doctor A: Chair the discussion and oversee the control steps. Reports to higher management on the care plans. Nurse A: Oversees the screening of nurses and prophylactic treatments. Ensures the nurses adhere to contact precautions and hand hygiene. Supervises the cleaning of fomites and environment. Case Manager: Trace all contacts of the diagnosed individual through digital or paper records. Contact them and refer them for treatment. Doctor B and Nurse B: Treat and reassess all cases of scabies. Provide treatment for contacts. Allied Health Representative: Ensure the allied health and other health care workers adhere to contact precautions and hand hygiene. Assist Case Manager in contact tracing.

\section{Recommendations}

It is imperative that early identification of the index case and subsequent contact tracing be performed during the onset of an outbreak; followed by treatment are the principles of management. High adherence to contact precautions and fomite cleaning are important steps that are often ignored.

Finally, continuous, vigilant surveillance of scabies in residential and long-term care facilities and activation of dedicated MDT teams to address the outbreak is the cornerstone of curbing scabies infestation in a long-term care institution.

Author Contributions: All authors are involved with conceptualization, writing, and approving the manuscript. Funding: This research received no external funding.

Conflicts of Interest: The authors declare no conflict of interest. 


\section{References}

1. Ramos-e-Silva, M. Giovan Cosimo Bonomo (1663-1696): Discoverer of the etiology of scabies. Int. J. Derm. 1998, 37, 625-630. [CrossRef] [PubMed]

2. Hengge, U.R.; Currie, B.J.; Jäger, G.; Lupi, O.; Schwartz, R.A. Scabies: A ubiquitous neglected skin disease. Lancet Infect. Dis. 2006, 6, 769-779. [CrossRef]

3. Walton, S.F.; Currie, B.J. Problems in diagnosing scabies, a global disease in human and animal Populations. Clin. Microbiol. Rev. 2007, 20, 268-279. [CrossRef]

4. Heukelbach, J.; Feldmeier, H. Scabies. Lancet 2006, 367, 1767-1774. [CrossRef]

5. Currie, B.J.; Connors, C.M.; Krause, V.L. Scabies programs in aboriginal communities. Med. J. Aust. 1994, 161, 636.

6. Heukelbach, J.; Wilcke, T.; Winter, B.; Feldmeier, H. Epidemiology and morbidity of scabies and pediculosis capitis in resource-poor communities in Brazil. Br. J. Derm. 2005, 153, 150-156. [CrossRef] [PubMed]

7. Holness, D.L.; DeKoven, J.G.; Nethercott, J.R. Scabies in chronic health care institutions. Arch. Dermatol. 1992, 128, 1257-1260. [CrossRef]

8. Parish, L.C.; Witkowski, J.A.; Mililikan, L.E. Scabies in extended care facility. Int. J. Dermatol. 1991, 30, 703-706. [CrossRef]

9. Cassell, J.A.; Middleton, J.; Nalabanda, A.; Lanza, S.; Head, M.G.; Bostock, J. Scabies outbreaks in ten care homes for elderly people: A prospective study of clinical features, epidemiology, and treatment outcomes. Lancet Infect. Dis. 2018, 18, 894-902. [CrossRef]

10. Romani, L.; Whitefield, M.J.; Koroivueta, J.; Kama, M.; Wand, H.; Tikoduadua, L. Mass Drug Administration for Scabies Control in a Population with Endemic Disease. N. Engl. J. Med. 2015, 37, 2305-2313. [CrossRef]

11. Karimkhani, C.; Colombara, D.V.; Drucker, A.M.; Norton, S.A.; Hay, R.; Engelman, D. Article The global burden of scabies: A cross-sectional analysis from the Global Burden of Disease Study 2015. Lancet Infect. 2015, 17, 1247-1254. [CrossRef]

12. Mounsey, K.E.; Murray, H.C.; King, M.; Oprescu, F. Retrospective analysis of institutional scabies outbreak from 1984 to 2013: Lessons learned and moving forward. Epidemiol. Infect. 2016, 144, 2462-2471. [CrossRef]

13. White, L.C.J.; Lanza, S.; Middleton, J.; Hewitt, K. The management of scabies outbreaks in residential care facilities for the elderly in England: A review of current health protection guidelines. Epidemiol. Infect. 2016, 144, 3121-3130. [CrossRef] [PubMed]

14. Bouvresse, S.; Chosidow, O. Scabies in healthcare settings. Curr. Opin. Infect. Dis. 2010, 23, 111-118. [CrossRef] [PubMed]

15. Utsumi, M.; Makimoto, K.; Quroshi, N.; Ashida, N. Types of infectious outbreaks and their impact in elderly care facilities: A review of the literature. Age Ageing 2010, 3, 299-305. [CrossRef] [PubMed]

16. Currie, B.J.; McCarthy, J.S. Permethrin and Ivermectin for Scabies. N. Engl. J. Med. 2010, 362, 717-725. [CrossRef]

17. Mellanby, K. Transmission of scabies. Br. Med. J. 1941, 2, 405-406. [CrossRef]

18. Mellanby, K. The development of symptoms, parasitic infection and immunity in human scabies. Parasitology 1944, 35, 197-206. [CrossRef]

19. Health Protection Programs and the Communicable Disease Control Branch; Department of Health and Ageing SA. Scabies Management in Care Facilities, 2012: Management Guidelines for the Control of Scabies in Health and Residential Care Facilities; Department for Health and Ageing, Government of South Australia: Adelaide, Australia, 2012.

20. Green, M. Epidemiology of scabies. Epidemiol. Rev. 1989, 11, 126-150. [CrossRef]

21. Arlian, L.G.; Morgan, M.S. A review of Sarcoptes scabiei: Past, present and future. Parasit. Vectors 2017, 10, 297. [CrossRef]

22. Haag, M.; Brozena, S.; Fenske, N.A. Attack of the scabies: What to do when an outbreak occurs. Geriatrics 1993, 48, 45-46. [PubMed]

23. Sterling, G.; Jamiger, C.; Kihiczak, G.; Schwartz, R.; Fox, M. Scabies. Am. Fam. Physician 1992, 46, $1237-1241$.

24. Chosidow, O. Scabies. N. Engl. J. Med. 2006, 354, 1718-1727. [CrossRef] [PubMed] 
25. Hewitt, K.; England, P.H.; Nalabanda, A.; Cassell, J. Scabies outbreaks in residential care homes: Factors associated with late recognition, burden and impact. A mixed methods study in England Scabies outbreaks in residential care homes: Factors associated with late recognition, burden and impact. A mixed methods study in England. Epidemiol. Infect. 2015, 143, 1542-1551. [CrossRef] [PubMed]

26. Tsutsumi, M.; Nishiura, H.; Kobayashi, T. Dementia-specific risks of scabies: Retrospective epidemiologic analysis of an unveiled nosocomial outbreak in Japan from 1989-90. BMC Infect. 2005, 5, 85. [CrossRef] [PubMed]

27. Currie, B.J.; Huffam, S.; O’Brien, D.; Walton, S. Ivermectin for scabies. Lancet 1997, 350, 1551. [CrossRef]

28. Cestari, T.F.; Martignago, B.F. Scabies, pediculosis, bedbugs, and stinkbugs: Uncommon presentations. Clin. Derm. 2005, 23, 545-554. [CrossRef]

29. Chosidow, O. Scabies and pediculosis. Lancet 2000, 355, 819-826. [CrossRef]

30. Elosua-González, M.; García-Zamora, E. Crusted scabies. N. Eng. J. Med. 2017, 377, 476. [CrossRef]

31. Lanza, S.; Middleton, J.; Head, M.G.; Bostock, J.; Nalabanda, A.; Walker, S.L. Can outbreak research be achieved in a population with impaired capacity? Findings from a study of a scabies outbreak in residential care. Lancet 2015, 386, S48. [CrossRef]

32. Sirera, G.; Romeu, J.; Ribera, M.; Tor, J.; Rius, F.; Llibre, J.M.; Soriano, V.; Ferrandiz, C.; Clotet, B. Hospital outbreak of scabies stemming from two AIDS patients with Norwegian scabies. Lancet 1990, 335, 1227. [CrossRef]

33. Estes, S.A.; Estes, J. Scabies research: Another dimension. Semin. Dermatol. 1993, 12, 34-38. [PubMed]

34. Esposito, L.; Veraldi, S. Skin bactrerial colonizations and superinfections in immunocompetent patients with scabies. Int. J. Dermatol. 2018, 57, 1218-1220. [CrossRef] [PubMed]

35. Hersch, C. Acute glomerulonephritis due to skin disease, with special reference to scabies. S. Afr. Med. J. 1967, 41, 29-34. [PubMed]

36. Woodley, D.; Saurat, J.H. The burrow ink test and the scabies mite. J. Am. Acad. Dermatol. 1981, 4, 715-722. [CrossRef]

37. Micali, G.; Lacarrubba, F.L.G.G. Scraping versus videodermatoscopy for the diagnosis of scabies: A comparative study. Acta Dermatol. Venereol. 1999, 79, 396.

38. Leung, V.; Miller, M. Detection of scbies: A systematic review of diagnostic methods. Can. J. Infect. Dis. Med. Microbiol. 2011, 22, 143-146. [CrossRef] [PubMed]

39. Dupuy, A.; Dehen, L.; Bourrat, E.; Lacroix, C.; Benderdouche, M.; Dubertret, L. Accuracy of standard dermoscopy for diagnosing scabies. J. Am. Acad. Dermatol. 2007, 56, 53-62. [CrossRef] [PubMed]

40. Argenziano, G.; Fabbrocini, G.; Delfino, M. Epiluminescence microscopy. A new approach to in vivo detection of Sarcoptes scabies. Arch. Dermatol. 1997, 133, 751-753. [CrossRef]

41. Brunetti, B.; Vitiello, A.; Delfino, S.; Sammarcco, E. Findings of in vivo of Sarcoptes scabiei with inident light microscopy. Eur. J. Dermatol. 1998, 8, 266-267.

42. Bauer, J.; Blum, A.; Sonnichsen, K.; Metzler, G.; Rassner, G.; Garbe, C. Nodular scabies detected by computed dermatoscopy. Dermatology 2001, 203, 190-191. [CrossRef] [PubMed]

43. Kuhn, C.; Lucius, R.; Matthes, H.F.; Meuseul, G.; Reich, B.; Kalinna, B.H. Characterisation of recombinant immunreactive antigens of the scab mite Sarcoptes scabiei. Vet. Parasitol. 2008, 153, 329-337. [CrossRef] [PubMed]

44. Casais, R.; Prieto, M.; Balseiro, A.; Solano, P.; Parra, F.; Martin Alonso, J.M. Identification and heterologous expression of a Sarcoptes scabiei cDNA encoding a structural antigen with immunodiagnostic potential. Vet. Res. 2007, 38, 435-450. [CrossRef] [PubMed]

45. Alasaaad, S.; Rossi, L.; Soriguer, R.C.; Rambozzi, L.; Soglia, D.; Perez, J.M. Sarcoptes mite from collection to DNA extraction: The lost realm of the neglected parasite. Parasitol. Res. 2009, 104, 723-732. [CrossRef] [PubMed]

46. Engelman, D.; Fuller, L.C.; Steer, A.C. Consensus criteria for the diagnosis of scabies: A Delphi study of international experts. PLoS Negl. Trop. Dis. 2018, 12, e0006549. [CrossRef] [PubMed]

47. Andersen, B.M.; Haugen, H.; Rasch, M.; Haugen, A.H.; Tageson, A. Outbreak of scabies in Norwegian nursing homes and home care patients: Control and prevention. J. Hosp. Infect. 2000, 160-164. [CrossRef] [PubMed]

48. Fitzgerald, D.; Grainger, R.J.; Reid, A. Interventions for preventing the spread of infestation in close contacts of people with scabies (Review). Cochrane Database Syst. Rev. 2014. [CrossRef] [PubMed] 
49. Chouela, E.; Abeldano, A.; Pellerano, G.; Hernandez, M.I. Diagnosis and treatment of scabies. Am. J. Clin. Dermatol. 2002, 3, 9-18. [CrossRef] [PubMed]

50. Schienfield, N. Controlling scabies in institutional settings: A review of medication, treatment models, and implementation. Am. J. Clin. Dermatol. 2004, 5, 31-37. [CrossRef] [PubMed]

51. Strong, M.; Johnstone, P. Interventions for treating scabies (Review). Cochrane Database Syst. Rev. 2010, 3 , CD000320.

52. Paasch, U.; Haustein, U.F. Management of endemic outbreaks of scabies with allethrin, permethrin, and ivermectin. Int. J. Dermatol. 2000, 39, 463-470. [CrossRef] [PubMed]

53. Ladbury, G.; Morroy, G.; van Hoeven-Dekkers, S.; Bottermans, C.; Veelenturf, C.; Bastiaens, M. An outbreak of scabies in multiple limked healthcare settings in the Netherlands. Infect. Control. Hosp. Epidemiol. 2012, 33, 1047-1050. [CrossRef] [PubMed]

54. Strong, M.; Johnstone, P. Cochrane review: Interventions for treating scabies. Evid.-Based Child. Health A Cochrane Rev. J. 2011, 6, 1790-1862. [CrossRef]

55. Mounsey, K.E.; Holt, D.C.; McCarthy, J.S.; Currie, B.J.; Walton, S.F. Longitudinal evidence of increasing in vitro tolerance of scabies mites to ivermectin in scabies-endemic communities. Arch. Dermatol. 2009, 145, 840-841. [CrossRef] [PubMed]

56. Currie, B.J.; Harumal, P.; McKinnon, M.; Walton, S.F. First documentation of in vivo and in vitro ivermectin resistance in Sarcoptes scabiei. Clin. Infect. Dis. 2004, 39, e8-e12. [CrossRef] [PubMed]

57. Khalil, S.; Abbas, O.; Kibbi, A.G.; Kurban, M. Scabies in the age of increasing drug resistance. PLoS Negl. Trop. Dis. 2017, 11, e0005920. [CrossRef] [PubMed]

58. Thomas, J.; Peterson, G.M.; Walton, S.F.; Carson, C.F.; Naunton, M.; Baby, K.E. Scabies: An ancient global disease with a need for new therapies. BMC Infect Dis. 2015, 15, 250. [CrossRef]

59. Roth, W. Scabies resistant to lindane $1 \%$ lotion and crotamiton $10 \%$ cream. J. Am. Acad. Dermatol. 1991, 24, 502-503. [CrossRef]

60. Mounsey, K.E.; Walton, S.F.; Innes, A.; Cash-deans SMcCarthy, J.S. In Vitro Efficacy of Moxidectin versus Ivermectin against Sarcoptes scabiei. Antimicrob. Agents Chemother. 2017, 61, 1-5. [CrossRef]

61. Mounsey, K.E.; Bernigaud, C.; Chosidow, O.; Mccarthy, J.S. Prospects for Moxidectin as a New Oral Treatment for Human Scabies. PLoS Negl. Trop. Dis. 2016, e0004389. [CrossRef]

62. Bernigaud, C.; Fang, F.; Fischer, K.; Lespine, A.; Aho, S.; Dreau, D. Preclinical Study of Single-Dose Moxidectin, a New Oral Treatment for Scabies: Efficacy, Safety, and Pharmacokinetics Compared to Two-Dose Ivermectin in a Porcine Model. PLoS Negl. Trop. Dis. 2016, 10, e0005030. [CrossRef] [PubMed]

63. Bhunu, C.P.; Mushayabasa, S.; Monera, T.G. Assessing the Impact of Vaccination on Controlling the Spread of Human Scabies. ISRN Comput. Bio. 2013, 2013, 362973. [CrossRef]

64. Liu, X.; Walton, S.; Mounsey, K. Vaccine against scabies: Necessity and possibility. Parasitology 2014, 141, 725-732. [CrossRef] [PubMed]

65. Karthikeyan, K. Treatment of scabies: Newer perspectives. Postgrad. Med. J. 2005, 81, 7-11. [CrossRef] [PubMed]

66. Wilson, M.G.; Philpott, C.D.; Breer, W.A. Atypical Presentation of Scabies Among Nursing Home Residents. J. Gerentol. Ser. A Biol. Sci. Med. Sci. 2001, 56, 424-427. [CrossRef]

67. Stoevesandt, J.; Carle, L.; Leverkus, M.; Hamm, H. Control of large istitutional settings: A review of medication, treatment models, and implementation. J. Dtsch. Dermatol. Ges. 2012, 10, 637-647. [CrossRef]

68. Sunderkötter, C.; Feldmeier, H.; Fölster-Holst, R.; Geisel, B.; Klinke-Rehbein, S.; Nast, A. S1 guidelines on the diagnosis and treatment of scabies-short version. JDDG 2016, 14, 1155-1167. [CrossRef]

69. Buehlmann, M.; Beltraminelli, H.; Strub, C.; Bircher, A.; Jordan, X.; Battegay, M. Scabies outbreak in an intensive care unit with 1,659 exposed individuals- key factors for controlling the outbreak. Infect. Control. Hosp. Epidemiol. 2009, 30, 354-360. [CrossRef]

70. Ejidokun, O.O.; Aruna, O.S.; O'Neill, B. A scabies outbreak in a further education college in Glouchestershire. Epidemiol. Infect. 2007, 135, 455-457. [CrossRef]

71. Vorou, R.; Remoudaki, H.D.; Maltezou, H.C. Nosocomial scabies. J. Hosp. Infect. 2007, 65, 9-14. [CrossRef]

72. California Department of Public Health. Prevention and Control Long-Term Care Facilities; California Department of Public Health: Sacramento, CA, USA, 2008. 
73. Jimenez-Lucho, V.E.; Fallon, F.; Caputo, C.; Ramsey, K. Role of prolonged surveillance in the eradication of nosocomial scabies in an extended care Veterans Affairs medical center. Am. J. Infect. Control. 1995, 23, 44-49. [CrossRef]

74. Yonkosky, D.; Ladia, L.; Gackenheimer, L.; Schultz, M.W.; Marlborough, M.P.H. Scabies in nursing homes: An eradication program with permethrin $5 \%$ cream. J. Am. Acad. Dermatol. 1990, 23, 1133-1136. [CrossRef]

75. Khan, A.; O' Grady, S.; Muller, M.P. Rapid control of a scabies outbreak at a tertiary care hospital without ward closure. Am. J. Infect. Control. 2012, 40, 451-455. [CrossRef] [PubMed]

(C) 2018 by the authors. Licensee MDPI, Basel, Switzerland. This article is an open access article distributed under the terms and conditions of the Creative Commons Attribution (CC BY) license (http:/ / creativecommons.org/licenses/by/4.0/). 